Hilde Marie Tvedten

M.A. Journalist.

\title{
Politisk flerstemmighet - hvordan skapes et partiprogram?
}

\section{Sammendrag:}

I denne artikkelen presenterer jeg en analysemetode som legger vekt på dialogen mellom tekster $i$ en retorisk situasjon. Med utgangspunkt i hovedfunnene fra min masteroppgave "Partiprogrammet som flerstemmig tekst - en retorisk genreanalyse av Arbeiderpartiets partiprogram 2009-2013 på bakgrunn av forslag som kom inn til programmet” gir jeg eksempler på hvordan denne metoden ble brukt til å analysere partiprogrammet som en dialogisk tekst, og jeg diskuterer om metoden kan være hensiktsmessig for andre analyser.

[Lenke til masteroppgaven: http://www.duo.uio.no/sok/work.html?WORKID=103415]

\section{Innledning}

Et partiprogram er, språklig-retorisk sett, en av de mindre umiddelbart tilgjengelige tekstene som kommer fra de politiske partiene. Partiprogrammenes offisielle funksjon er å informere velgerne og det politiske system for øvrig om de respektive partienes politikk på spesifiserte områder (Narud og Valen 2004: 33). I min masteroppgave (Tvedten 2010) valgte jeg å se nærmere på prosessen som gikk forut for teksten i partiprogrammet. Utgangspunktet har vært at selv om det ikke er så tydelig på overflaten, har en stor gruppe mennesker, mange diskusjoner og mange skriftlige og muntlige innspill vært en del av denne prosessen. Spørsmålet er i hvilken grad dette har satt preg på teksten.

I analysen har jeg sett på fire ulike forslag og innspill til partiorganisasjonen fra enkeltpersoner, interessegrupper og lokallag har satt sitt preg på teksten. De fire forslagene presenterer et eller flere tiltak innenfor områdene rusomsorg, forholdet mellom frivillig og offentlig sektor, skole og Forsvaret.

I denne artikkelen vil jeg presentere hvordan jeg har jobbet med å utvikle en metode som tar utgangspunkt i prosessen som pågår når disse forslagene blir inkludert. Metoden forankres i teorien om dialogisme, og er delt opp i to trinn: På bakgrunn av en analyse av dialogen mellom forslagene og partiprogrammet, viser jeg hvordan dialogen mellom partiprogrammet og publikum foregår. Jeg viser deretter hvordan sentrale genretrekk ved partiprogrammet kan gjenkjennes i ulike tekstlige trekk ved forslagstekstene. Disse trekkene danner grunnlaget for min definisjon av partiprogrammet som en ekstern og intern kontrakt, med et publikum både innad i partiet og utad mot velgerne. Dette kan igjen forklare hvorfor Det norske Arbeiderparti (heretter Arbeiderpartiet) fremstår med en sterk lederstemme på tross av de mange innspillene til teksten. Analysen av hvordan tekstskapingsprosessen 
påvirket partiprogrammet, blir utgangspunkt for en diskusjon om hvor stort demokratisk potensial som ligger i prosessen.

\section{Problemstillinger og forskningsspørsmål}

Det som gjør akkurat denne tilnærmingen særlig aktuell, er at Arbeiderpartiet i 2008 gikk mer aktivt til verks for å få inn forslag til hva partiprogrammet skal inneholde. «(...)Det er første gangen man har åpnet opp arbeidet med partiprogrammet på den måten. Det handler også om at vi innser som parti at vi kan ikke bare vcere innadrettet», sier Hadia Tajik, medlem i programkomiteen, i et intervju jeg gjorde med henne i forbindelse med oppgaven. Hun poengterer at partiprogrammet både har en intern og ekstern funksjon (jf. Narud og Valen 2004), men selvlegger hun mest vekt på verdien det har for politikerne i hverdagen: «Aller viktigst for partiet selv er den interne: Partiprogrammet er mer, vil jeg si, et grunndokument som vi bruker som partiorganisasjon i alt det vi senere produserer, alt det som måtte være av valgkampmateriell eller det som måtte vœre av praktisk politisk arbeid». Slik kan vi forstå partiprogrammet som utgangspunkt for andre tekster som i større grad er laget for å kommunisere direkte med velgerne.

For partiets del ser det ut til at en slik kontakt med velgerne blir stadig viktigere, spesielt gjennom satsingen på kommunikasjon gjennom internett. Arbeiderpartiet er aktivt både i blogger, på Facebook og på Twitter. Våren 2010 inviterte Arbeidernes ungdomsfylking til Facebook-chat om sitt internasjonale program. Her forklarer de hvordan de i årets programprosesser kommer til å bruke nettsamfunnet “mittArbeiderparti.no” til å la enda flere delta i programprosessene enn tidligere. Flesteparten av forslagene til partiprogrammet kom likevel gjennom epost, og denne kommunikasjonsformen mangler mange av de sosiale medienes dialogiske muligheter. Vi kan imidlertid også se det som at internett som medium har åpnet nye rom for den politiske talen: Fysisk sett bryter det ned romlige barrierer, for eksempel mellom territoriale politiske samfunn på alle nivåer. Det gir interessegrupper makt til å flytte seg fra sin vanlige krets, og kan ses på som «(...) en delvis sammenhengende, delvis usammenhengende, sammenvevende og foranderlig konstellasjon[...] av politiske forum og arenaer (...)» (Raab og Bellamy 2004: 18).

På bakgrunn av dette forsøkte jeg å svare på to problemstillinger i masteroppgaven:

- Hvordan kan man lage en modell for å analysere politisk retorikk som tar hensyn til prosessen som fører fram til en politisk tekst?

- Hvordan kan denne innsikten brukes til å forstå partiprogrammet som genre og dets politiske funksjon?

\section{Diskusjonstemaer}

Arbeiderpartiets egne tiltak for å utvide debatten rundt partiprogrammet var en av grunnene til at jeg ble interessert $\mathrm{i}$ å undersøke partiprogrammet som dialogisk tekst. Tidligere har 
Arbeiderpartiet arbeidet mer lukket med sitt eget partiprogram, men dette forandret seg i 2008, da det ble opprettet en ny og mer eller mindre fungerende arena som hadde som mål å åpne denne prosessen. På Arbeiderpartiets hjemmeside, www.dna.no, ble da medlemmer og andre interesserte invitert til selv å bidra til programdebatten:

Debatten om Arbeiderpartiets program blir landets viktigste verksted i tiden frem til landsmøtet skal vedta programmet våren 2009. Programkomitéen vil legge opp en prosess der alle medlemmer i partiet, og alle andre interesserte, skal inviteres til å komme med innspill og delta i debattene(...).

Det kom inn 8000 forslag til programkomiteen.

Det finnes allerede en del forskning om hvordan internettet påvirker deltakelsen i demokratiet. Hanne Hestvik (2004) viser til to teoretiske retninger innenfor forskningen på dette feltet: mobiliseringstesen, som ser på digital teknologi som revolusjonerende, noe som vil utvide adgangen til den politiske arena, og normaliserings-/forsterkningstesen, som baserer seg på at ny teknologi alene ikke kan revolusjonere etablerte samfunnsstrukturer og mønstre.

Når det gjelder Arbeiderpartiets partiprogram som genre, er det viktig å også se på hva slags historiske forutsetninger som har vært med på å påvirke genren. Arbeiderpartiets egne politiske tradisjoner, talemåter og ideologi er selvsagt en viktig del av dette. Både partiets politiske stilling gjennom etterkrigstida, partidemokratiet i Norge og den nåtidige politiske konteksten har hatt sin påvirkning på partiprogrammet.

Helt grunnleggende kan man se partiprogrammet som en tekst som faller inn under én av de tre retoriske hovedgenrene, slik Aristoteles beskrev dem: den politisk-rådgivende talen som uttrykt gjennom deliberativ retorikk. Partiprogrammets funksjon kan forstås som å anbefale eller fraråde ulike tiltak på et bredt spekter av politiske områder slik partiet mener de skal gjennomføres i den neste stortingsperioden. Utgangspunktet i denne genren kan også ses i sammenheng med begrepet deliberasjon, som man kan forstå som rasjonell kommunikasjon i ideelle talesituasjoner (Dryzek 2000). Dryzek beskriver deliberasjon som en sosial prosess, som skiller seg fra andre måter å kommunisere på. De som deltar i deliberasjonen er mottakelige for å forandre sine vurderinger, preferanser og syn gjennom samhandlingen, som involverer overtalelse i stedet for tvang, manipulasjon og bedrageri. Hvordan forslagene får betydning i partiprogrammet, kan ses i sammenheng med spørsmålet om det faktisk foregår en slik deliberasjon. Hva slags påvirkning har internettet på den kommunikasjonen som foregår? Vi kan se dette i sammenheng med begrepet deltakerdemokrati, som kan forstås som et program for bredt folkelig engasjement, deltakelse og medbestemmelse i ulike faser av beslutningsprosesser (Østerud 2002: 139). Her må de avgjørelsene som tas, kunne tilbakeføres til åpne og utvungne debatter mellom likeverdige deltakere.

Flere demokratiteoretikere mener at makrodemokratier bygges av mikrodemokratier, og i denne koplingen blir oppmerksomheten først og fremst rettet mot partier som demokratiske organisasjoner. I slike betraktninger står både spørsmålet om formelle beslutningsstrukturer og reelle debattmuligheter sentralt (Skjeie 1999: 19). Den ideelle 
talesituasjonen for deliberasjon er nettopp et ideal, men vi kan bruke den som et utgangspunkt for å diskutere noen av deliberasjonens vilkår og begrensninger. Sagt på en annen måte, kan vi spørre om det virkelig er et mikrodemokrati som utarbeider partiprogrammet, og om dette kan ha en innflytelse på makrodemokratiet.

Disse spørsmålene vil jeg prøve å svare på ved å analysere teksten basert på prosessen bak den. Et sentralt spørsmål er om en undersøkelse av språket i partiprogrammet kan fortelle noe om det politiske arbeidet og den demokratiske kvaliteten i det.

\section{Teoretisk grunnlag}

En slik metode må ta utgangspunkt i en forståelse av språket som handling på flere nivåer. Det trengs et samlende begrep som tar høyde den mangfoldige tekstskapingsprosessen. Målet i masteroppgaven var å svare på problemstillingene gjennom en dialogisk tilnærming til analysen av partiprogrammet. Tilnærmingen tar utgangspunkt i at tekster som kommer forut for partiprogrammet, setter sine spor i den endelige teksten; Mikhail Bakhtins forståelse av det dialogiske er at all forståelse av levende tale, av levende ytring, har en aktivt svarende karakter (Bakhtin 1998:10-11). Jeg vil i det følgende forsøke å vise hvordan partiprogrammet som tekst kan forstås som et svar på de forslagene som har kommet inn. Ved å invitere folk til å komme med forslag, og bruke dem i tekstdiskusjonen og -produksjonen, har partiet selv lagt opp til å la programmet bli et aktivt svar på disse forslagene.

Det er selvfølgelig umulig å få oversikt over all kommunikasjon i en slik prosess. Både interne møter, politiske allianser og konflikter, og også rene tilfeldigheter, kan ha påvirket teksten i det 60 sider lange partiprogrammet. Men med en dialogisk tilnærming der jeg tar høyde for noen sider ved denne prosessen, håper jeg å komme nærmere hvordan de mange deltakerne bidrar til å gjøre partiprogrammet til en flerstemmig tekst.

At ytringer har en aktivt svarende karakter, utdyper Bakhtin med at alle ytringer har en gjensidig påvirkning på hverandre: «Alle ytringar er fulle av gjenklangar og gjenlydar av andre ytringar som dei er knytte saman med i det fellesskapet som den aktuelle sferen for talekommunikasjon utgjer» (1998: 35). Denne erkjennelsen kopler han til to begreper som vi begge kan forstås som illustrasjon på at en ytring er påvirket av mange stemmer.

Det første er begrepet om “heteroglossia” eller “flerstemmighet”. En heteroglossisk ytring forstår jeg her som en ytring som rommer flere motsetningsfylte stemmer (jf. Raddum og Veum 2006: 145). En slik tilnærming til flerstemmighet kan være nyttig for å forstå hvordan teksten hører hjemme $\mathrm{i}$ en institusjonell kontekst der uenighet er en del av programarbeidet.

Samtidig kan en dialogisk tilnærming belyse om partiprogrammet er en polyfonisk tekst, der de ulike stemmene har egne "melodier". Polyfoniens motsetning er homofoni, en term for flerstemmighet hvor én stemme er den ledende mens de andre stemmene akkompagnerer. Ofte vil det flerstemmige ligge et sted mellom det homofone og det polyfone (Tønnesson 2002: 221, 226). I partiprogrammet er det sentralt å undersøke om stemmen/stemmene i forslagene skiller seg fra stemmen/stemmene i partiprogrammet, om de 
er motsetningsfylte i utgangspunktet, og i hvilken grad forskjeller og motsetninger kommer til syne i den endelige programteksten.

\section{Å undersøke politisk ideologi}

Teksten i et program eller en enkelt programpost vil ofte inneholde argumentasjon som formidler politiske «sannheter» slik partiet forstår dem. Men disse er ikke alltid like lette å se klart for seg for leserne av partiprogrammet. Hos de aller fleste velgerne finnes det en grunnleggende forståelse av hva Arbeiderpartiet står for, selv om det kanskje ikke er det samme som Arbeiderpartiet selv mener. Samtidig må Arbeiderpartiet kommunisere sin politikk klart, men det er heller ingen mulighet til å gå inn på de historiske forutsetningene og den politiske bakgrunnen for alle tiltakene som foreslås. Her finnes det et spenningsnivå mellom hva som forstås av partiet internt og hva som kan tas for gitt eksternt blant velgere, interessegrupper, andre partier og andre mottakere av teksten.

Spesielt i forhold til argumentasjonen trengs det et kritisk søkelys på dette spenningsforholdet mellom deltakerne som både er tekstskapere og mottakere av tekst. Norman Fairclough mener at det å ha kritiske mål, vil si å kaste lys over det som kan forstås som naturaliserte ideologiske representasjoner. Fairclough tegner en skala av naturalisering av ideologien, der det mest naturaliserte er representert av en proposisjon som blir oppfattet som allment, eller «common sense», av alle medlemmer av et visst samfunn (Fairclough 1995: 31). I arbeidet med partiprogrammet har jeg sett på hvordan ideologi framstår i naturalisert form, enten det er partiet sentralt eller interne eller eksterne forslagsstillere som ytrer seg.

\section{Utvikling av en dialogisk metode}

\section{Materiale}

Partiprogrammet til Arbeiderpartiet 2009-2013, som ble vedtatt våren 2009, er et omfattende dokument med tittelen «Skape og dele». I min analyse har jeg tatt for meg fire forslag som har kommet inn til partiet, og som partiet selv oppgir har ligget til grunn for teksten i selve partiprogrammet: Et forslag fra Sunndal Arbeiderparti om rusomsorg, et fra FN-veteranenes landsforbund om veteraners rettigheter, ett fra Hørselshemmedes landsforening om samarbeidet mellom frivillig og offentlig sektor, og ett fra Anne Ragnhild Kjær Sti, tidligere aktiv på lokalnivå i partiet, om en database til bruk i skolen. Delene av partiprogrammet som blir analysert, har det samme tematiske innholdet som forslagene. De fire tekstene i partiprogrammet har titlene er «Storsatsing mot rusmisbruk», «Forsvarsutfordringer» «Frivillighet og velferd» og «En god nasjonal fellesskole».

En svakhet ved dette utvalget er at ingen av forslagene som ble forkastet, er undersøkt. Utvalget er også gjort såpass lite for å gjøre plass til en grundig analyse av de fire tekstene. Men det er også begrenset fordi partiet selv identifiserte hvilke forslag det vurderte som viktige. Fordelen med et så lite utvalg er muligheten for å gjøre en grundig analyse av leksikogrammatiske trekk, språkhandlinger og argumentasjon i tekstene. 


\section{Genrebegrepet og analysemetode}

Det teoretiske utgangspunktet er altså at partiprogrammet som ytring må forstås ut fra av andre ytringer det er knyttet sammen med. I tillegg til de konkrete forslagene som har kommet inn, må det også ses på bakgrunn av andre politiske tekster og tidligere partiprogram. Det er altså behov for å se nærmere på hva som kjennetegner den deliberative retorikken i partiprogrammet. En del av kjennetegnene ved partiprogrammet som genre har vi allerede vært inne på, men for å undersøke genren videre, må vi komme nærmere inn på hvordan tekstskapingsprosessen fungerer dialogisk.

For å forstå nettopp dette, trengs det en pragmatisk forståelse av genre som handling. Carolyn Miller tar utgangspunkt i Lloyd F. Bitzers teori om den retoriske situasjon for å forstå genre som typifiserte retoriske handlinger (Miller 2001). Bitzer forstår retorikken som noe som oppstår fordi en bestemt situasjon innbyr til at det sies noe, og kjernen i denne retoriske situasjonen er et påtrengende problem (exigence), som kan løses ved hjelp av språklig handling (Bitzer 1997: 11f). Partiprogrammet, som lanseres i forkant av en ny fireårsperiode, ser jeg som én av flere tekster som oppfyller følgende påtrengende problem: velgerne og medlemmene av partiet må få kjennskap til partiets politiske og ideologiske ståsted.

Sentralt i den retoriske situasjonen står også de tvingende omstendighetene, også kalt de retoriske vilkårene, som utgjøres av “de personer, hændelser, genstande og relatoner som er dele av situationen fordi de har magt til at afgrcense og fremtvinge de beslutninger og handlinger som er nødvendige for at afhjclpe det påtrengende problem” (Bitzer 1997: 13). De fire forslagene som ble med videre i arbeidet med partiprogrammet, er blitt akseptert som retoriske vilkår. De har i kraft av seg selv, og sin retoriske utforming, fått makt i tekstskapingsprosessen. Men utgangspunktet for denne makten er at noen i partiet mente at forslag fra medlemmer og enkeltpersoner burde utgjøre en sentral del av de retoriske vilkårene. Vi kan se det slik at det har oppstått en ny retorisk situasjon, der forslagene responderer på et påtrengende problem som er en eksplisitt invitasjon til å gi innspill til programkomiteen i arbeidet med å utforme partiprogrammet.

Vi har altså to retoriske situasjoner og to påtrengende problemer, der den sistnevnte situasjonen der forslagene oppstår - aldri ville ha oppstått om det ikke hadde vært for partiprogrammets retoriske situasjon. Vi kan beskrive hvordan forslagenes retoriske situasjon (2) blir en del av vilkårene i partiprogrammets retoriske situasjon (1) med denne modellen: 


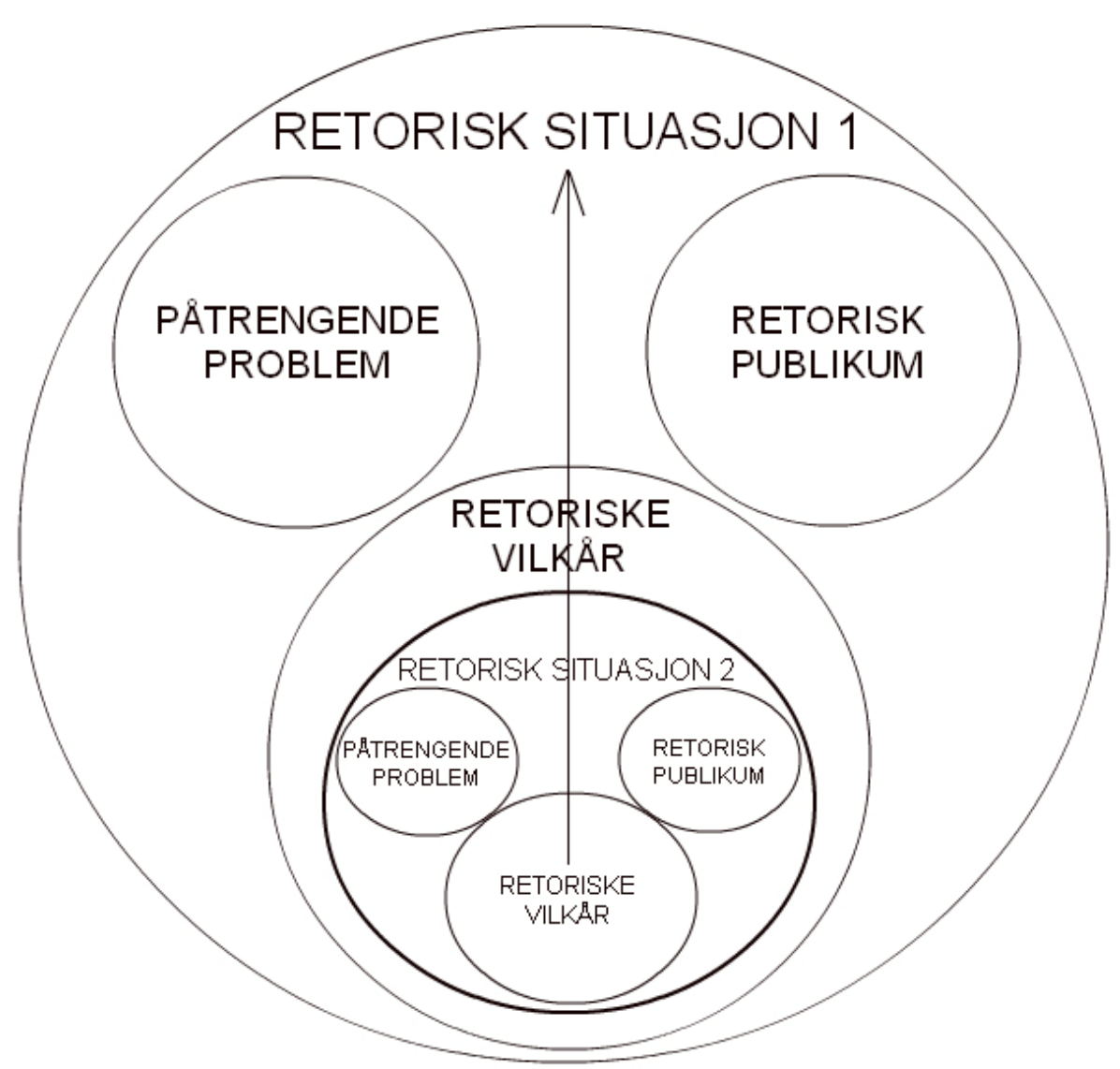

Jens Kjeldsen tar til orde for en reformulering av teorien om den retoriske situasjon, og vil si at "retorisk kommunikasjon skaper og skapes av retoriske situasjoner, og retoriske situasjoner skaper og skapes av retorisk kommunikasjon" (2009: 60). Denne retoriske situasjonen illustrerer hvorfor en dynamisk tilnærming som dette er viktig. Spesielt gjør den det gjennom det siste konstituerende element i en retorisk situasjon: publikum. I partiprogrammets retoriske situasjon (1) er det velgerne og medlemmene i partiet som er publikum for teksten. Men samtidig er de invitert til å være skapere av egne ytringer. I forslagenes retoriske situasjon (2) er det partiet selv som er publikum. Rollene snus altså om i de to retoriske situasjonene.

Det er opphavet til å undersøke hvordan to helt konkrete dialoger kommer til uttrykk gjennom teksten:

- Dialogen mellom forslagene og partiprogrammet

- Dialogen mellom partiprogrammet og velgerne

Dermed blir den retoriske situasjonens kompleksitet et utgangspunkt for å forklare genren, og dialogen mellom tekstene et utgangspunkt for å undersøke dens flerstemmige karakter. 


\section{Detaljert metode for tekstanalyse}

Denne ganske komplekse situasjonen er altså utgangspunktet for å forstå partiprogrammet som genre. Men hvordan skal vi beskrive genrens formelle trekk? Tidligere forskning har beskrevet genrer på ulike måter og ulike nivåer i teksten. Dialogismen legger vekt på interaksjonelle og kontekstuelle trekk ved menneskelig diskurs, handling og tenkning (Linell 1998: 34). For å gjøre en nærmere analyse av teksten i et dialogisk perspektiv, må vi derfor ta i bruk verktøy som gjør det mulig å studere disse aspektene ved språket.

Her forsøker jeg å få tak på flerstemmigheten i genren, og hva som kjennetegner denne flerstemmigheten. Bakhtin mener det er to momenter som definerer ytringens kompositoriske og stilistiske særtrekk: ytringens tematiske innhold og ytringens ekspressivitet, dvs. talerens subjektive, emosjonelt-evaluerende forhold til det tematiske innholdet i ytringen (1998: 27). Denne ekspressiviteten eller subjektiviteten uttrykker, og kan derfor forstås gjennom å undersøke det Michael Halliday kaller den mellompersonlige metafunksjonen i språket (Halliday og Matthiessen 2004: 30). Dette er språklig mening som etablerer og opprettholder sosiale forhold og som uttrykker talerens holdninger og vurderinger. I konkrete ytringer realiseres dette mellompersonlige meningsaspektet primært gjennom modus og modalitet. Modalitet beskrives av Halliday som «the speaker's judgement, or request of the judgement of the listener, on the status of what is being said» (2004: 143). A forstå flerstemmighet på bakgrunn av (blant annet) modalitet har flere gjort før meg (Raddum og Veum 2006, Veum 2008). I stedet for bare å se på modalitet, har jeg også tatt for meg hvordan modalitet samsvarer med fire grunnleggende språkhandlinger, som bare delvis er sammenfallende med Searles mer utbredte taksonomi: konstatering, spørsmål, tilbud og ordre (Halliday og Matthiessen 2004: 34).

Ytringens tematiske innhold kan man se i sammenheng med hvordan tekstene bruker argumentasjon for å uttrykke politiske vurderinger. Bakhtin beskriver det som at ytringen representerer også talerens aktive posisjon i en eller annen tematisk sfære (1998: 27). Jeg tar utgangspunkt i Stephen Toulmins teori om argumentasjon, som ser et arguments hovedfunksjon som rettferdiggjørende. Hans modell ser et argument som delt i tre elementer påstand, belegg og hjemmel. Normalt vil vi ha noen fakta som blir presentert som grunnlaget som påstanden er basert på (Toulmin 2008: 90). I partiprogrammet er teksten ofte bygget opp slik at de konkrete tiltakene presenteres på bakgrunn av noen mer generelle betraktninger om hvordan politikken bør være.

For den detaljerte næranalysen av hver tekst henviser jeg til min masteroppgave. Å gå inn i dette her vil bli for omfattende, men nedenfor presenterer jeg hvordan jeg har tenkt i arbeidet, og kommet fram til analysens resultater.

\section{Resultat av analysen: To stemme-strategier}

Første steget i analysen var, som jeg beskrev tidligere, å undersøke dialogen mellom forslagstekstene og programtekstene. Det sentrale funnet var at de fire forslagene brukte to 
ganske ulike retoriske strategier for å overbevise partiet om at forslaget var verdt å ta med i partiprogrammet. Dette resultatet skal jeg forklare ved å bruke noen eksempler fra analysetekstene. Sitatene er hentet fra pdf-versjonen av Arbeiderpartiets partiprogram, og fra forslagene, som finnes som vedlegg i masteroppgaven.

Den første strategien er å tilpasse seg Arbeiderpartiets måte å formulere seg på. To forslag som har ført til konkrete tiltak som omtales i partiprogrammet, benytter denne strategien. Det første er forslaget fra FN-veteranenes Landsforbund om å styrke veteranenes rettigheter; det andre er Anne Ragnhild Kjær Sti sitt forslag om å opprette en nasjonal skoledatabase. Det siste forslaget kan brukes som eksempel. Her beskriver hun først bakgrunnen for forslaget, og deretter fremsettes det sentrale forslaget. Formen er språkhandlingen tilbud: «Ap ønsker derfor å opprette en nasjonal database med blant annet undervisningsopplegg, planarbeid og materiale til bruk i kontakten mellom skole og hjem.»

Dette er også en typisk måte å formulere seg på i partiprogrammet: Tilbudene blir uttrykt hovedsakelig gjennom modalverb som vil. I tillegg viser dette eksemplet at den teksteksterne avsenderen av forslaget, enkeltpersonen bak det, ikke er synlig i teksten som et subjektivt jeg.

Argumentasjonen i forslaget bygger på begreper som er kjente for Arbeiderpartiet, blant annet begrepet fellesskole og argumenter som tar utgangspunkt i en sosialdemokratisk «delekultur». Når vi nøster opp i hvordan teksten argumenterer for den nasjonale databasen, ser vi også at den gjennom andre språklige virkemidler etablerer en ideologisk plattform som samsvarer med Arbeiderpartiets egne grunnverdier. Vi ser det i de enkle formuleringene som fungerer som en hjemmel for argumentasjonen - altså det som knytter påstanden om databasen sammen med bakgrunnsinformasjonen: «Hvis vi skal oppnå alle målene $i$ Kunnskapsløftet, er det helt nødvendig at hele skole-Norge drar i samme retning og kan dra nytte av hverandres kompetanse og ideer.»

Den andre strategien er å tematisere dialogen mellom forslagsteksten og partiprogrammet. Her kommer avsenderen mer til syne i teksten. De to andre forslagene bruker denne strategien for å presentere det som er bredere tanker om og tiltak rundt ulike temaer - rusomsorg og frivillig sektor. Vi kan bruke det sistnevnte, fra Hørselshemmedes landsforening (HLF), som eksempel. Forslaget argumenterer hovedsakelig for denne påstanden: «Etter vår oppfatning bør det systematiseres en samhandling mellom offentlig sektor og frivillig sektor innen helse og omsorg på områdene rehabilitering, forebygging og kompetanseutvikling.»

I teksten markerer HLF seg som en aktør som stiller krav til Arbeiderpartiet gjennom bruk av modalverbet må og det vi kan forstå som en variant av språkhandlingen ordre: «Arbeiderpartiet må ta opp i seg at det er et klart skille mellom private løsninger og velferdstilbud fra offentlig sektor.» $\AA$ velge frivillig sektor fremfor privat sektor er et viktig poeng for HLF, som blant annet begrunner denne påstanden med en implisitt hjemmel: Det er ikke bra å ha kommersiell drift som mål. Gjennom sine egne implisitte antakelser viser HLF at de ikke deler Arbeiderpartiets ideologiske plattform, og vi kan se en mer reell diskusjon rettet mot det som er Arbeiderpartiets ståsted på dette området. 
Hva skjedde språklig med forslagene i forhold til partiprogrammet? Den første strategien førte til et konkret punkt i teksten i partiprogrammet som handler om en nasjonal fellesskole. I slutten av hvert avsnitt i programmet finnes en liste der det ramses opp ulike konkrete tiltak under overskriften Arbeiderpartiet vil. Her finnes forslaget fra Kjær Sti som ett punkt: (Arbeiderpartiet vil): «opprette en nasjonal database med blant annet undervisningsopplegg, planarbeid og materiale til bruk i kontakten mellom skole og hjem.» (s. 19).

Ingen av de konkrete argumentene for dette i Kjær Stis forslag er tatt med i programmet, men vi ser at forslaget føyer seg inn som en naturlig oppfølging av Arbeiderpartiets egen argumentasjon for ulike skoletiltak. Sagt på en annen måte: Den ideologiske plattformen tillater at dette konkrete forslaget følger i Arbeiderpartiets omtale av hvordan deres fellesskole ser ut.

Den andre strategien kan også ha ført til en påvirkning på selve partiprogrammet, selv om dette er vanskelig å si like sikkert. Forslaget til HLF har ikke ført til noe konkret tiltak i en liste. Vi finner likevel igjen formuleringer fra forslaget i setningen: «Arbeiderpartiet ønsker å videreutvikle samhandlingen mellom offentlig sektor og ideelle organisasjoner for å bedre tjenestetilbudet til befolkningen» (s. 50). Men oppfordringen om at Arbeiderpartiet må ta opp i seg at privat sektor skiller seg fra offentlig og frivillig sektor, blir ikke fulgt i partiprogrammet. I stedet legger argumentasjonen for frivillig sektor seg ikke opp i privat sektors betydning. Vi ser her at forslaget om at det bør systematiseres en samhandling omformuleres til et tilbud fra Arbeiderpartiet i at de ønsker å videreutvikle samhandlingen. I en slik formulering forplikter ikke Arbeiderpartiet seg i særlig stor grad til dette tilbudet.

Hva er da suksesskriteriene for at forslagene blir tatt videre? Eksemplene tyder på at den første strategien er mest vellykket. Den har ført til et konkret punkt i programmet, og nærmer seg Arbeiderpartiets egen måte å formulere seg på gjennom tilbud til velgerne, og deres egen argumentasjon gjennom den samme ideologiske plattformen.

\section{Hovedfunn: Et flerstemmig partiprogram?}

I analyseeksemplet over har jeg demonstrert hvordan en stemme kan komme til uttrykk gjennom språkhandlinger og gjennom eksplisitt eller implisitt argumentasjon. Den har også gitt en pekepinn om hvordan Arbeiderpartiets stemme i partiprogrammet skiller seg fra eller ligner forslagenes stemme. Det forklarer også, slik jeg ser det, hvordan dialogen mellom partiprogrammet og velgerne foregår.

En oppsummering av hvordan denne stemmen fungerer mellompersonlig og argumentativt, viser også hvordan partiprogrammets politiske funksjon kommer til syne gjennom tekstanalysen. Funnene fra analysen illustrerer de ulike delene av Øyvind Østeruds mer politisk orienterte definisjon av genren partiprogram (2002: 168f).

For det første kan vi se det slik at programmet uttrykker en forholdsvis systematisk oppfatning om hvordan verden er. Denne blir uttrykt gjennom det som er blitt naturalisert som ideologisk «common sense». Det vil si at argumentasjonen bygger opp en ideologisk plattform, blant annet gjennom uttrykk som fellesskolen, som i eksemplet om databasen i 
skolen. Men dette skjer også gjennom de implisitte hjemlene i argumentasjonen. Et eksempel på dette vises tydelig i forskjellen på hvordan Arbeiderpartiet og HLF vurderer privat sektors rolle i argumentasjonen sin, som jeg beskrev over. De bruker også formuleringer som skjuler at det ligger en vurdering bak, på samme måte som forslaget om skoledatabasen argumenterer med at noe er helt nødvendig. Denne siden ved partiprogrammet understreker den interne funksjonen det har som en ideologisk plattform for partiets og medlemmene, og illustrerer som vi har sett den institusjonelle diskursive tilknytningen til Arbeiderpartiet.

For det andre uttrykker programmet hvordan verden bør vœre. Det gjøres gjennom påstander om hvordan sider ved henholdsvis rusomsorgen, forsvarspolitikken, frivillig sektor og skolepolitikken bør prioriteres. Språkhandlingen ordre og modalitet uttrykt gjennom ord som må, skal og trenger er typiske eksempler. På samme måte som forslagsteksten stilte krav til hva Arbeiderpartiet må, fremmer de altså selv noen krav. Men hvem er disse kravene rettet mot? I realiteten dem selv, gjennom å vise til hvordan de vurderer ulike politiske prioriteringer. Noen eksempler som også er hentet fra de andre tekstene, er: Alle ledd $i$ rusomsorgen må styrkes, og det må innføres klare kvalitetskriterier, eller Særlig må Forsvaret være $i$ stand til å løse de utfordringer Norge kan komme til å stå overfor i nordområdene. Denne måten å formulere seg på, uttrykker Arbeiderpartiets subjektive vurderinger, men stemmen forplikter seg ikke nært til disse vurderingene.

For det tredje uttrykker programmet hvordan målene eventuelt kan virkeliggjøres. Det skjer gjennom formuleringer som er gjennomgående i programteksten: tilbud til velgerne. Arbeiderpartiet vil og ønsker er typiske slike formuleringer. Arbeiderpartiet vil bygge opp en framtidsrettet rustjeneste er ett eksempel. Et annet er forslaget om en nasjonal skoledatabase, som ble plassert sammen med en liste over tiltak med overskriften Arbeiderpartiet vil. Etter Hallidays forståelse av modalitet uttrykker dette ikke noen grammatisk høy forpliktelse til disse tilbudene til velgerne. Jeg forstår det likevel som de klareste politiske løftene i programmet.

Denne beskrivelsen av Arbeiderpartiets stemme i partiprogrammet viser også hvordan partiprogrammet fungerer som politisk genre. Hvordan Arbeiderpartiet uttrykker en systematisk oppfatning av hvordan verden er, understreker den interne funksjonen partiprogrammet har: Det fungerer som en ideologisk plattform som blir utgangspunkt for et diskursivt fellesskap for partiet og medlemmene. Som jeg nevnte i innledningen, legger partiet selv stor vekt på den verdien programmet har som et referansedokument for partiet selv.

De to andre punktene fungerer i større grad eksternt gjennom å kommunisere politiske prioriteringer og løfter overfor potensielle velgere. Begge disse sidene ved partiprogrammet kan sies å uttrykke en dialogisk kontrakt mellom Arbeiderpartiet på den ene siden, og partimedlemmene og velgerne på den andre siden.

Det eksterne og interne perspektivet påvirker også det jeg mener fremstår som stemmen til Arbeiderpartiet i genren. Arbeiderpartiets stemme er institusjonelt knyttet til genren, og rettes mot et bredt ekstern og internt publikum. Det mener jeg er hovedgrunnen til at den tekstinterne stemmen viser Arbeiderpartiet som et stort «vi» som ikke synliggjør de mange som har bidratt til teksten, eller de diskusjonene og konfliktene som har pågått. Selv om prosessen med å lage partiprogrammet henter inn mange stemmer, er det vanskelig å 
kjenne dem igjen i teksten. Partiprogrammet må ses på som en homofonisk tekst med en sterk lederstemme, som i liten grad tar inn språklige impulser fra forslagene som skiller seg fra genrens språk.

\section{Diskusjon: Deliberasjon og demokratisk potensial}

Tidligere i artikkelen lanserte jeg noen teorier om hvordan forslagene kan ha fått hatt en verdi ut over seg selv, og lanserte potensialet for at de setter i gang en demokratiserende deliberasjonsprosess. Hva har analysen vist? Vi har sett at strategien som tar utgangspunkt i å tilpasse seg Arbeiderpartiets stemme, fikk mest gjennomslag i partiprogrammet. Vi kan se det som at de klarer å knytte det spesielle til det generelle, som er et vilkår for at de bør bli deltakende i deliberasjonen (Dryzek 2000: 167). Samtidig krever dette god kjennskap til Arbeiderpartiets ideologiske plattform før forslagene sendes inn. Det er medstemmer, ikke motstemmer, som får påvirkningskraft i partiprogrammet. Dette er også en av forklaringene på den tydelige homofoniske stemmen: Stemmene forstår de institusjonelle kodene, og klarer å tilpasse seg.

Forslagene til programmet har blitt tilpasset partiets ideologiske diskurs og måter å formulere løfter og tiltak på. Som medstemmer føyes disse stemmene altså inn i Arbeiderpartiets store $v i$ i teksten, som fremstår som en institusjonell helhet som kommuniserer ut mot et bredt publikum. Det er liten grunn til å kritisere at det er slik, i og med at Arbeiderpartiet faktisk har søkt etter konstruktive forslag som på en eller annen måte samsvarer med deres tidligere politikk.

Det er også vanskelig ut fra denne analysen å uttale seg bastant om hva slags demokratisk potensial internett har i en slik prosess. Det er ikke bare enkeltforslagene, men forslagenes tematiske innhold som helhet, som kan gi partiet en ny måte å få oversikt over offentlig mening på. På den andre siden har vi sett at forslagene har større sjanse til å bli tatt med i programmet dersom de viser kjennskap til partiets ideologiske plattform og til genren. Det er ikke sikkert det er nye deltakere som kommer til i debatten gjennom nettet, bare at debatten flyttes et annet sted. Dermed heller jeg mer til å forstå dette ut fra normaliserings/forsterkingstesen som jeg beskrev tidligere.

Arbeiderpartiet har historisk vært en av de fremste representantene for massepartiet, der velgerne deltok aktivt i partiarbeidet (Heidar og Saglie 2002: 43-45). Hvis vi ser på programdebatten i et medlemsdemokratisk perspektiv, kan vi se den nye teknologien som et middel for å utvide mulighetene for den politiske debatten innad i partiet. Selv om det ikke nødvendigvis er nye deltakere som kommer til, kan det åpne for en bredere og mer engasjerende debatt. Tekstanalysen viser hvordan et slikt mikrodemokrati kan finnes igjen i teksten i partiprogrammet. 


\section{Verdien av metoden}

Partiprogrammet illustrerer etter min mening at politikk er mer enn taler og debatter. Jeg har gitt noen eksempler på hvordan en tekst som kan oppfattes som tung og byråkratisk, kan analyseres ved å se på dialogen som ligger bak teksten, og hvordan denne kommer til syne i den publiserte teksten. Svakheten er at man aldri kan få en uttømmende forståelse av en politisk prosess gjennom en tekstanalyse. På den andre siden er det få andre metoder som kan påberope seg å få til det. Et supplement til en slik analyse kunne vært å ta større høyde for de politiske konfliktdimensjonene, og å undersøke hvordan de kommer til syne i partiprogrammet.

Den helt konkrete analysen av forslag og ferdig tekst er et innspill til hvordan man kan analysere tekster i uoversiktlige og flytende retoriske situasjoner. Når ulike kanaler på nettet blir stadig viktigere for partiene, bør det også bli et viktigere område for tekstforskningen framover.

\section{Litteratur}

Arbeiderpartiets partiprogram 2009-2013: http://arbeiderpartiet.no/content/download/26061/372182/version/1/file/Skape+og+del e+-+Arbeiderpartiets+program+2009+-+2013.pdf

Bakhtin, M.M. (1953-54/1998): Spørsmålet om talegenrane. Oversatt av Rasmus T. Slaattelid. Ariadne Forlag, Oslo.

Bitzer, L.F. (1997 [1968]): Den retoriske situation. I: Rhetorica Scandinavica nr 3, 1997

Dryzek, J.S. (2000): Deliberative democracy and beyond. Liberals, critics, contestations. Oxford University Press, Oxford.

Fairclough, N. (1995): Critical Discourse Analysis. The Critical Study of Language. Longman, Harlow.

Halliday, M.A.K. og C.M.I.M. Matthiessen (2004): An introduction to functional grammar. Third edition. Arnold, London.

Heidar, K. og J. Saglie (2002): Hva skjer med partiene? (Makt og demokratiutredningen, 1998-2003). Gyldendal Akademisk, Oslo.

Hestvik. H. (2004): «valgkamp2001.no». Partier, velgere og nye medier. Ny kommunikasjon? I: Aardal, B., A. Krogstad og H. M. Narud (red.) (2004): I valgkampens hete. Strategisk kommunikasjon og politisk usikkerhet. Universitetsforlaget, Oslo.

Kjeldsen, J. E. (2009): Retoriske omstcendigheter. Retorikken i en fragmenteret, foranderlig og kompleks verden. I Rhetorica Scandinavica nr. 48, 2009. Retorikförlaget AB, Åstorp.

Linell, P. (1998): Approaching Dialogue. Talk, Interaction and Contexts in Dialogical Perspective. John Benjamins, Amsterdam.

Miller, C. (2001 [1984]): Genre som sosial handling. I Rhetorica Scandinavica nr. 18, 2001 
Narud, H.M. og H. Valen (2004): Partiprogram og velgerappell. I: Aardal, B., A. Krogstad og H. M. Narud (red.): I valgkampens hete. Strategisk kommunikasjon og politisk usikkerhet. Universitetsforlaget, Oslo

Raab, C. D. og C. Bellamy (2004): Electronic democracy and the «mixed polity». Symbiosis or conflict? I: Gibson, R. K., A. Römmele og S. J. Ward (red.) (2004): Electronic Democracy. Mobilisation, organisation and participation via new ICTs. Routledge, London og New York.

Raddum, T. og Veum, A. (2006): Avistekstens mange stemmer. Artikkel i Norsk Medietidsskrift 13 (2). Norsk medieforskerlag.

Skjeie, H. (1999): Vanens makt. Styringstradisjoner i Arbeiderpartiet. Makt- og demokratiutredningen 1998-2003. Ad Notam Gyldendal, Oslo.

Toulmin, S.E. (2008): The Uses of Argument. Updated edition. Cambridge University Press, London.

Tvedten, H.M. (2010): “Partiprogrammet som flerstemmig tekst - en retorisk genreanalyse av Arbeiderpartiets partiprogram 2009-2013 på bakgrunn av forslag som kom inn til programmet”. Masteroppgave ved ILN, UiO. Duo-link:

Tønnesson, J. L. (red.) (2002): Den flerstemmige sakprosaen. Nye tekstanalyser. Fagbokforlaget, Oslo.

Veum. A. (2008): Avisas andlet: førstesida som tekst og diskurs: Dagbladet 1925-1995. Doktoravhandling ved Det humanistiske fakultet, Universitetet i Oslo/Unipub Østerud, Ø. (2002): Statsvitenskap. Innføring i politisk analyse. Universitetsforlaget, Oslo.

\section{På nett \\ http://arbeiderpartiet.no/Aktuelt/Nyhetsarkiv/Web-og-sosiale-medier/Facebook-premiere-i- programarbeid}

http://web.archive.org/web/20080416040318/www.arbeiderpartiet.no/dna.no/Programdebatt 